\title{
ON THE ORIGINS OF SACRED ARCHITECTURE: INTERPRETATIONS OF THE EGYPTIAN TEM- PLE
}

\section{ALLE ORIGINI DELL'ARCHITETTURA SACRA: INTER- PRETAZIONI DEL TEMPIO EGIZIO}

\author{
Maurizio Pagano ${ }^{1}$ \\ Università del Piemonte Orientale (Vercelli)
}

\begin{abstract}
Secondo l'interpretazione di Hegel gli edifici religiosi egiziani, e tra essi in particolare i templi, rappresentano l'inizio della storia dell'architettura, e con ciò di tutta la storia dell'arte.

L'architettura religiosa egiziana ha un carattere simbolico, perché la sua forma cerca di rappresentare il contenuto spirituale senza esservi pienamente adeguata. Così il tempio egizio allude al divino con la sua intera struttura, ma non ha propriamente un interno, dedicato al culto dell'immagine del dio.

L'egittologia contemporanea ha corretto Hegel su questo punto, perché in generale il tempio egizio aveva un interno che custodiva l'immagine della divinità. Tuttavia la tesi di Hegel rimane paradossalmente valida per un caso particolare dell'esperienza egiziana, che egli non poteva conoscere: nella religione monoteista di Amarna il tempio del dio solare Aton non ha immagini e non ha un centro, perché il divino è presente dappertutto, come la luce del sole, che illumina egualmente ogni parte del tempio..
\end{abstract}

Parole chiave: Egitto; architettura; tempio; simbolo; immagine.

Abstract: According to the interpretation of Hegel, Egyptian religious buildings, and among them especially the temples, represent the beginning of the history of architecture, and so the beginning of the entire history of art.

[1] Curriculum: Maurizio Pagano è professore ordinario di Filosofia Teoretica nell'Università del Piemonte Orientale (Vercelli) ed è Direttore del Centro Studi Filosofico-religiosi "Luigi Pareyson" di Torino. Ha pubblicato il volume Hegel. La religione e l'ermeneutica del concetto, ESI: Napoli 1992. Inoltre ha curato il volume: Lo spirito. Percorsi nella filosofia e nelle culture, Mimesis: Milano - Udine 2011.

Maurizio Pagano is Professor of Theoretical Philosophy at the University of Eastern Piedmont (Vercelli) and is Director of the Centro Studi Filosofico-religiosi "Luigi Pareyson" of Turin. He published the volume Hegel. La religione e l'ermeneutica del concetto, ESI: Napoli 1992. He also edited the book: Lo spirito. Percorsi nella filosofia e nelle culture, Mimesis. Milano - Udine 2011.

maurizio.pagano@uniupo.it 
The Egyptian religious architecture has a symbolic character, because its configuration tries to represent the spiritual content without being fully adequate to it. So the Egyptian temple alludes to the divine through its entire structure, but does not have a proper internal space, dedicated to the worship of the image of God.

On this point, contemporary Egyptology corrected Hegel's view, because broadly speaking the Egyptian temple had an interior where the image of the deity was safeguarded. However, Hegel's thesis paradoxically remains suitable for a particular case of the Egyptian experience that he could not know at that time: in the monotheistic religion of Amarna, the temple of the sun-god Aton has no images and does not have a center, because the Divine is present everywhere, like the sunlight that illuminates equally all over the temple.

Key words: Egypt; architecture; temple; symbol; image.

\section{On the origins of sacred architecture: interpretations of the Egyptian temple}

Egyptian religious buildings, and particularly the temples, are some of the most ancient and impressive testimonies of human civilization. According to Hegel's interpretation, they mark the real beginning of the history of architecture, and so the beginning of the entire history of art.

Art begins in Egypt thanks to the particular degree of maturity that religious consciousness had reached in that civilization. The history of religion in fact accompanies the entirety of human experience since its earliest stages, and during its course it gives rise to the art as well as, later on, to philosophy. On one hand Egypt captures for the first time the spiritual meaning of divinity, thanks to the conception of Osiris as a god who dies and rises again, and on the other hand it develops an initial understanding of human subjectivity, as testified by the cult of the dead ones.

In the Egyptian religious experience, we therefore meet an early discovery of spirituality, and this is what gives rise to art. In his mature theory, exposed in the Berlin lectures of Aesthetics, Hegel will present the development of art as a route that takes place through three art-forms, namely the symbolic, the classical, and the romantic. To these forms, corresponds the flourishing of the various arts, in the way that architecture corresponds to the symbolic art and sculpture to the classical, while the romantic art is expressed in painting, music and poetry. Egypt corresponds to architecture and is the embodiment of the symbolic art par excellence. Moreover, even its religious consciousness finds its proper expression on the ground of the symbol: the symbol represents a particular stage of development of the human spirit, which has already overcome the level of 
the immediate intuition, and now is rising to the level of representation; however, it is just the beginning of this higher sphere.

In the Phenomenology of Spirit, Hegel does not have the notion of the symbol yet; however, already in this work he attempts an interpretation of the Egyptian spirit. We find this text in the section on Religion; it introduces the figure of the Artificer (Werkmeister), in which culminates the natural religion of the East and where the transition to the Greek religion is prepared ${ }^{2}$. This text connects tightly the artistic to the religious dimension, and anticipates, in a dense and concise form, many issues that Hegel will develop in his mature works. The Egyptian artificer is the figure of the spirit that emerges from nature and tries to understand himself. It is not able to grasp himself in thought yet, but tries to express himself through his productive activity, and to find himself in his own work. His activity is a kind of «instinctive operation», a real struggle with organic reality, to which he tries to give a spiritual form: precisely this very struggle is the genesis of architecture and sculpture. The work of the artificer, at the beginning, is dominated by the abstraction of the understanding, it is expressed in rigorous forms (straight lines, flat surfaces) which are opposed to the fullness of natural life. The pyramid is the first form of architecture, the obelisk anticipates what will be the sculpture. Later on, these forms will be developed, and the abstraction of strict forms, which express the work of a subject still stiff and focused on himself, will have to meet the fullness of the multiple forms, encountered in nature: in order to achieve the «surrounding habitation», that is to say the temple, the author tries to realize a mediation between the straight lines and curves, and thus to produce the «animated curve» of the column. This very «mixture» of natural and abstract forms is «the root of free architecture.»

On the other hand the Egyptian artificer begins to feel the need to give to this architectural work an interior, that is to say, to insert in it a singular figure, which represents the deity. This is the task of the sculpture: it uses firstly the animal figure, it makes it «the hieroglyph» of a thought, of a spiritual significance. This mixture, however, is still imperfect, and a sense of abstraction remains even when the artificer unifies the animal to the human figure. The Egyptian artificer fails to resolve this struggle between the spiritual and the natural element, and the outcome remains enigmatic; also the structure of the temple remains uncertain, sometimes its interior is merely an empty space, or perhaps occupied by a shapeless stone, as reported by Herodotus on the temple of Buto. Egypt

[2] Hegel, G. W. F.: Phänomenologie des Geistes, in Gesammelte Werke, Hamburg: Meiner, 1980, vol. IX, pp. 373-375; Phenomenology of Spirit, trans. by A. V. Miller, Oxford: Oxford Univ. Press, 1977, pp. 421-424. 
remains an enigma to itself, one that will be solved only in the artistic religion of the Greeks.

Hegel resumes his work on Egypt during the period of his teaching in Berlin (1818-31), which is also the last period of his life. The underlying thread of the analysis is offered by the philosophy of religion: in the development of religious consciousness, Egypt represents a milestone for two interconnected reasons. First, in Egypt the importance of negation is caught for the first time, and thus it is introduced in the divinity: Osiris is for Hegel the god who dies and rises again; with Osiris, the divine ceases to be an abstract and motionless substance, acquires concrete characteristics of spirituality, and enters into the realm of representation. Correspondingly, the human being is caught in its subjectivity, as it is testified in the cult of the dead and the belief in immortality (Hegel follows Herodotus on this point, who had wrongly attributed to the Egyptians the belief in metempsychosis).

This early discovery of spirituality, however, is still affected by nature: it is not expressed in conceptual thinking, but in the symbol. Egyptian consciousness passed over the sphere of the immediate intuition, entered in the thinking dimension of representation, but still remains unstable. It captures a universal meaning that begins to order the natural experience, but it is not its master, and thus it is sent back again and again to the natural sphere, and it feels the need to make this conquest perceivable. The spiritual element that is coming forth to the consciousness wants to be manifested, wants to become visible; and consciousness can only catch it in the form of natural intuition: thus, this intuition has to be no longer considered in its pure immediacy, but it is not the allegory of a meaning already given; it is an intuition that leads to a deeper meaning, which only in this intuition comes to expression. For that reason Egypt is «the country of the symbol», as declared in the Aesthetics", and the Egyptians are "the people of the Symbol», as it is said in the lecture of $1826^{4}$. In Egypt the question of the "self-decodification of the Spirit» has been raised, even if it remains unsolved. In fact, here the spirit is still searching itself in the outwardness, it works tirelessly to make manifest the inner, the spiritual, in the outer, in the works: for that reason, Egyptians, as declared in the Aesthetics, are "the real people of the Art.» Egypt expresses thoroughly the religious and artistic essence of the symbol, which is marked precisely by

[3] Hegel, G. W. F.: Vorlesungen über die Ästhetik, in Werke, Suhrkamp: Frankfurt, 1970, vol. XIII, p. 456; Aesthetics. Lectures on Fine Art, trans. by T. M. Knox, Oxford: Calderon Press, 1975, vol. I, p. 354.

[4] Philosophie der Kunst oder Ästhetik. Nach Hegel. Im Sommer 1826. Mitschrift F. C. H. V. von Kehler, ed. by A. Gethmann-Siefert, J. - I. Kwon and B. Collenberg-Plotnikov, Fink: München, 2004, p. 85. 
this discrepancy between the meaning and the form, between the inside and the outside. On this ground the discrepancy is unbridgeable, because the inside is not caught in a complete manner, that is, in a way that it could give to itself a fully adequate external form, as it will occur in Greek art. Thus, the appropriate image of symbolic art is the pyramid, a "crystal», in which is conserved a dead body ${ }^{5}$.

This clarification of the concept of symbol offers to Hegel the thread to determine the character and the development of Egyptian religious architecture. Certainly the activity of building has always accompanied the human experience, and we could think that in its early stages had been realized in the production of huts or in the excavation of the caves, in order to build habitable spaces. This activity, which is limited to the response to a need, is not however art yet: in order to have art, a manifestation of the spirit is required, and the first of these manifestations is to give form to what is objective, like the ground or the external environment, and thus to impress a spiritual meaning on what is devoid of interiority. The first, really accomplished realization of this artistic architecture will be the construction of a dwelling for the image of a god. However, this stage already includes a division between the external aspect of the architecture and its inner purpose, and therefore it cannot be the first manifestation of this art. In the first step, Hegel argues, we should find artworks that have not this division and this reference yet: they must be autonomous and carry their meaning in themselves. This is precisely the case of symbolic architecture: its early works are almost an inorganic sculpture, but they are distinguished from sculpture because they do not create a figure that expresses spirituality directly, but merely allude to it, precisely with their architectural structure.

However, this first stage of architecture is unstable: it must strive, for its very nature, to become functional, to distinguish its outwardly work from its inner purpose. So it strives to produce more concrete forms much similar to the sculpture, but they retain an architectural character for their colossal proportions: Hegel mentions here the obelisks, the sphinxes, and the colossal statues of Memnon placed on the edge of the valley at Thebes. Even the majestic Egyptian temples are situated in this phase: in these huge buildings we find a large number of sphinxes, of memnons, of columns and arcades, which can have individually a precise symbolic function, but above all they contribute to form a set, still symbolic in its overall meaning. It is true that we also find a shrine, but according to the sources

[5] Hegel, G. W. F.: Vorlesungen über die Philosophie der Kunst. Berlin 1823. Nachgeschrieben von H G. Hotho, in Vorlesungen. Ausgewählte Nachschriften und Manuskripte, vol. II, ed. by A. Gethmann-Siefert, Meiner: Hamburg, 1998, p. 218. 
(Strabo and Herodotus) it is of a modest size, and contains no image of the god or at most an animal figure, or even a monolith.

Even in the Aesthetics, therefore, Hegel reconfirms his interpretation of the Egyptian temple, which is situated in the sphere of symbolic art, although the need to transform itself into a functional building, designed to keep in the inside the image of the god, seems to come into light. This step is outlined more clearly in the pyramids: as monuments that serve as dwellings for the dead, they acquire - at least in part - an instrumental character. Even today, these immense crystals provoke the greatest admiration; at the same time they testify that the Egyptians, through the veneration of the dead ones, had begun to grasp the value of the spirit and the value of the dimension of individuality. It may appear surprising that Hegel considers the pyramids as a more advanced form than the temples, which are developed in Luxor and in the Valley of the Temples in the second half of the second millennium BC; however, we must consider that the Greek sources, particularly Herodotus, suggested a chronology which is quite confused, and did not allow to ascribe pyramids to the period of the Old Kingdom.

The problem of the interpretation of the Egyptian civilization, especially for its art and for its religion, was a much discussed topic in Hegel's time. On this point it was still alive the controversy between the Enlightenment and the romantic perspectives. The first position is well represented by Arnold Hermann Ludwig Heeren, authoritative historian of Göttingen, while the second one finds one of the most significant expressions in the Symbolic of Friedrich Creuzer, philologist and mythologist of Heidelberg, and friend of Hegel. Heeren resumes the doctrine, developed in the eighteenth century, that considers religion as a deception of the priests and he uses it to offer a reductionist reading of the Egyptian religion. Creuzer, instead, emphasizes the symbolic value of the Egyptian wisdom, and sees it as a trace of the primitive revelation of a unique God ${ }^{6}$. The other great representative of idealism that is passionately dedicated to the interpretation of the Egyptian religion is Schelling: however, in his lectures on the philosophy of mythology, he focuses essentially on the interpretation of the contents of Egyptian mythological consciousness, and dedicates a few pages, in the eighteenth lecture, to the monuments of this civilization; here he faces primarily the issue of setting a date for construction of the several temples, and then he focuses on the pyramids

[6] Heeren, A. H. L.: Ideen über die Politik, den Verkehr und den Handel der vornehmsten Völker der alten Welt, Göttingen 1793-96, vol. I, pp. 331-478; Creuzer, F.: Symbolik und Mythologie der alten Völker, besonders der Griechen, Leipzig and Darmstadt, 1819-21², vol. I, pp. 240-532. 
and the question, still uncertain for him, of their meaning. This brief overview demonstrates, in my view, the uniqueness of Hegel's reflection on the interpretation of the temples and generally on the role that the Egyptian religious architecture assumes in the development of human civilization.

Naturally, contemporary Egyptology, developed on scientific basis, has enormously expanded our knowledge on these topics. Particularly, thanks to the knowledge of the Egyptian writing, it has been highlighted the meaning of the rituals and the role of the temple as the seat of worship. Hegel's thesis on the lack of a shrine was radically revisited: as a matter of fact, the temple dedicated to a deity was considered by the Egyptians as the place where to worship the cult-image of the god. However, the issue of the relationship between the temple and the images remains central even today: as shown by the researches of Erik Hornung and Jan Assmann on the religion of Amarna, the monotheistic revolution of Akhenaton introduces a terrible break in the history of Egyptian religion, exactly because the Pharaoh prohibits not only festivities and processions, but the cults and the images of the gods. The new temple of the sun-god Aton has no images, and does not have a real center, because the Divine is present everywhere like the sunlight: as sunlight gives life to every part of the earth, it illuminates equally every part of the temple. However, the Egyptian people will not support the revolution of the monotheistic Pharaoh and right after his death, traditional religion will be restored, and will continue to have the temple and the worship reserved for the gods in it as its main features. 
$-106-$ 